\title{
Effects of Knee Extension Exercise Using Blood Flow Restriction on the Thickness and Balance Ability of Tendons
}

\author{
Jae-Cheol Park', Yong-Nam Kim² \\ 'Department of Physical Therapy, Graduate School, Nambu University, Gwangju, ²Department of Physical Therapy, Nambu University, Gwangju, Korea
}

Purpose: This study examined the effects of knee extension exercise using blood flow restriction on the changes in the thickness and static balance ability of the tendon of the rectus femoris muscle and achilles tendon.

Methods: A total of 30 subjects was were divided into two groups of 15 subjects each. The changes in the thickness and balance of their tendons were measured by ultrasonography and balance equipment. The measurements were taken three times: before the experiment, 4 weeks after, and 8 weeks after. The results were analyzed by repeated measure ANOVA, one-way ANOVA was conducted in cases where there were time-to-group interactions in the intra-individual effects test.

Results: Significant differences in the thickness of the tendon of the rectus femoris muscle and Achilles tendon were found between the groups, over time, and in the time-to-group interactions $(p<0.05)$. The changes in balance in both feet when the supporting positions between eye-open and eye-closed states were significantly different in the time-to-group interactions $(p<0.05)$, but were not different between the groups ( $p>0.05)$.

Conclusion: Knee extension exercise using blood flow restriction leads to significant differences in the increase in tendon thickness and changes in balance, indicating that the results of this study can be utilized as basic data for future studies and for rehabilitation treatment at clinics.

Keywords: Blood flow restriction, Tendon, Balance, Ultrasonography

\section{서 론}

힘줄은 근육을 뼈에 연결해 장력을 견디게 하는 질긴 섬유성 결합조 직으로 힘줄 모세포와 혈관내피세포, 연골세포, 데코린(decorin) 및 히알루론산(hyaluronan) 등의 프로테오글리칸(proteoglycan)과 I형 교 원섬유로 구성되고 종적인 방향으로 잘 정렬된 세포 외기질을 이루 고 있으며, ${ }^{1}$ 역학적 문제와 허혈성 원인으로 인해 손상이 발생한다. ${ }^{2}$ 힘줄 손상은 물리치료 분야 근골격계 질환 중 흔한 질환이며 매년 수 많은 사람이 무릎, 어깨, 발목의 힘줄 손상으로 고통을 받고 있다. 힘 줄 손상이 발생하면 비정상적인 관절 움직임과 생체역학적 변화를 유발하여 장기적으로 퇴행성 관절염을 유발한다. ${ }^{3}$ 힘줄은 혈액 공급 이 부족하고 힘줄 세포(tenocytes)의 재생 능력이 나쁘기 때문에 한 번 손상된 힘줄은 많은 재활 기간이 필요하며, ${ }^{4}$ 방법 또한 일반적으로 물리치료 분야에서 수용할 접근 방법이나 보전적 치료나 보조기 또 는 석고붕대로 고정밖에 없다. 보조기와 석고 고정 방법은 회복까지

Received Mar 6, 2018 Revised Apr 16, 2018

Accepted Apr 23, 2018

Corresponding author Yong-Nam Kim

E-mail kyn0231@nambu.ac.kr
오랜 시간과 일생생활동작의 제약, 근 위축이 발생하는 단점이 있으 므로 손상 전 강화를 통한 예방이 가장 중요하다. ${ }^{6}$

물리치료 분야에서 힘줄을 강화하는 방법이 많지 않지만, 혈류제 한 운동이(blood flow restriction exercise) 힘줄을 강화할 수 있는 대안 적 접근 방법으로 가능성이 있다. 혈류제한 운동은 팔, 다리에 혈류 제한 커프를 이용하여 말단으로 흐르는 혈류를 일시적 제한함으로 써 활동 근육과 주변 조직의 혈액순환 동태를 변화시키는 특징이 있 고, 저강도 운동만으로도 고강도 저항운동 효과와 비슷한 근 비대 와 근력 향상을 유발한다. ${ }^{8}$ 혈류제한은 근력의 향상.9 근두께 증가, ${ }^{10-12}$ 밀도와 백색영역지수 증가, ${ }^{13}$ 지구력 개선, ${ }^{14}$ 성장호르몬 분비 증가, ${ }^{15,16}$ 신생혈관 증가가 보고되었다. ${ }^{17}$ Evans 등 ${ }^{18}$ 은 성인 9명을 대상으로 혈 류제한을 이용한 저강도 훈련을 4 주간 시행 후 신생혈관의 증가로 인 해 혈관 여과능력이 향상되었다는 보고와 혈류제한 운동으로 인해 신생 모세혈관이 대조군보다 증가했다고 보고하여, ${ }^{19}$ 혈관이 부족하 여 힘줄 강화에 어려움이 있는 관절 주변에 혈액순환 변화가 발생하
Copylight ( 2018 The Korea Society of Physical Therapy

This is an Open Access article distribute under the terms of the Creative Commons Attribution Non-commercial License (Http:// creativecommons.org/license/by-nc/4.O.) which permits unrestricted non-commercial use, distribution, and reproduction in any medium, provided the original work is properly cited. 
여 힘줄 강화에 이득이 있을 것이라는 가설을 세우고 본 연구를 설계 하였다.

선행연구들을 통해서 혈류제한 운동의 긍정적인 효과에 대해 보 고들은 많지만, 혈류제한을 적용하고 관절의 안정성에 관여하는 힘 줄 두께 변화를 초음파를 이용한 영상 구조적 특성변화에 관한 연구 는 전혀 없는 실정이다.

따라서 본 연구는 무릎과 발목 안정성에 관여하는 넙다리네갈래 근 힘줄과 아킬레스힘줄의 두께 변화와 정적 균형능력 변화에 혈류 제한 운동이 어떠한 영향을 미치는지 연구하려고 하며, 혈류제한을 이용한 무릎 폄 운동이 넙다리곧은근 힘줄과 아킬레스힘줄의 두께 의 구조적 변화를 초음파로 분석하고 균형능력 기기를 사용하여 정 적 균형에 변화를 알아봄으로써 임상에서 재활프로그램에 기초자 료를 제공하여 활용하는 데 목적이 있다.

\section{연구방법}

\section{1. 연구대상}

본 연구에 참여한 대상자는 20 대 성인 30 명으로 혈류제한 무릎 폄 운 동군에 남자 5 명, 여자 10 명 총 15 명을 일반적 무릎 폄 운동군은 남자 5 명, 여자 10 명 총 15 명씩 두 군으로 나누어 실험을 진행하였다. 대상 자의 선정 기준은 연구에 대한 충분한 설명을 듣고 자발적으로 실험 에 참여 의사를 표현한 자로 사전 동의서를 작성 후 실험에 참여하였 다. 내·외과적 질환 및 근골격계 질환이 없는 자와 수축기 혈압이 140 $\mathrm{mmHg}$ 이상 확장기 혈압이 $90 \mathrm{mmHg}$ 를 넘지 않는 자로 실험 전 6개 월 이상 정기적인 운동을 하지 않는 자로 연구자의 임의배정 방식에 의하여 무작위 선정하였으며 군에 대한 정보를 대상자에게 설명하지 않고 군에 따른 중재의 차이가 있을 거라는 내용만 설명한 다음 단일 맹검법(single-blind test)에 의한 대상자를 선정하였다. 연구 대상자의 일반적 특성은 다음과 같다(Table 1).

\section{2. 실험방법}

실험군의 혈류제한을 위하여 수은식 혈압계를 이용하여 만든 간이

Table 1. General characterisrics of subjects

\begin{tabular}{lccc}
\hline & BKE $(\mathrm{n}=15)$ & $\mathrm{KE}(\mathrm{n}=15)$ & $\mathrm{p}$ \\
\hline Age (year) & $21.26 \pm 1.16$ & $21.20 \pm 1.26$ & 0.271 \\
Height $(\mathrm{cm})$ & $162.26 \pm 5.95$ & $166.0 \pm 8.91$ & 0.162 \\
Weight $(\mathrm{kg})$ & $49.80 \pm 8.74$ & $56.13 \pm 10.84$ & 0.127 \\
BMI $\left(\mathrm{kg} / \mathrm{m}^{2}\right)$ & $18.78 \pm 1.95$ & $20.20 \pm 2.31$ & 0.502 \\
Gender & & & \\
Male & 5 & 5 & \\
Female & 10 & 10 & \\
\hline
\end{tabular}

BKE: blood flow restriction knee extension exercise, KE: knee extension exercise BMl: body mass index.
혈류제한 커프를 엉덩관절과 무릎관절의 사이 몸쪽 부위 각각 좌. 우 다리에 운동이 방해되지 않게 적용하였다. 혈류제한을 위해 압력 은 바로 누운 자세에서 1 주부터 4 주까지 $150 \mathrm{mmHg}$ 압력을 주었고 4 주차부터 8 주까지 $200 \mathrm{mmHg}$ 압력을 증가시켜 적용했다. 운동 자세 로는 바로 앉은 자세에서 무릎 아래에 압력 바이오피드백(Chattanooga, USA) 쿠션을 배치하여 시각적 피드백으로 이용하여 바이오피 드백 압력은 $80 \mathrm{mmHg}$ 의 압력까지 공기를 주입 후 운동 시작과 동시 에 $140 \mathrm{mmHg}$ 압력까지 정적 무릎 폄 운동을 하였고, 대조군은 혈류 제한 커프만 미적용하여 무릎 폄 운동을 하였다. 중재는 8 주간 주 3 회 1 일 30 분씩 설정하여 준비운동, 마무리운동 5 분 동안 시행하였고 20 분간 본 운동 프로그램을 세트당 15 회씩 반복하고 총 5 세트하였으 며 세트 간 1 분 휴식하도록 하였다.

\section{3. 측정도구}

\section{1) 초음파영상측정}

힘줄의 두께 변화 측정을 위해 초음파 영상장치(V2u Health Care, Singapore)를 사용하였다. 이 장치의 주파수 변조 범위는 $6.5-8.5 \mathrm{MHz}$ 이며, gain의 범위는 20-80이고, 변환기는 $3.5 \mathrm{MHz}$ 선형탐촉자(linear transducer)를 이용하였다. 검사자 간의 차이를 최소화하기 위해 다리 의 해부학적 지식과 초음파 검사기에 숙달된 물리치료사 1 인을 측정 자로 선정하였고 측정시기별 측정부위를 정확하게 유지하기 위해 수 술용 펜으로 표시 후 시행하였다. 넙다리곧은근 힘줄 두께 측정 자세 는 넙다리곧은근의 안정적 길이가 유지되도록 높이가 조절되는 침상 에 앉은 후 발을 침상 밖으로 내리게 하였다. 그 후 무릎 뒤에 쿠션을 배치하여 편안한 위치인 80 도 굽힌 상태에서 변환기를 종으로 배치 하여 넙다리뼈와 무릎뼈, 종아리뼈를 확인한 후 무릎뼈와 종아리뼈 를 연결하고 있는 넙다리곧은근 힘줄을 초음파 화면 중앙에 위치하 게 하여 측정하였다. 아킬레스힘줄의 측정 자세는 바로 엎드린 자세 에서 발목에 쿠션을 배치하여 발등 굽힘이 되지 않게 하였고, 변환기 를 세로로 배치하였다. 초음파 화면에서 발꿈치뼈가 왼쪽에 위치하 게 하고 오른쪽에 있는 가자미근과 장딴지근을 확인한 후 초음파 화 면 가운데에서 아킬레스힘줄 두께를 측정하였다. 변환기를 이용하여 측정된 힘줄 이미지를 초음파에 내장된 캘리퍼를 이용하여 힘줄 두 께를 측정하였고, 우측 넙다리곧은근 힘줄과 아킬레스힘줄을 총 3 회 반복 측정한 후그 평균값을 힘줄의 두께로 정하였다.

\section{2) 균형 장비}

균형 능력을 측정하기 위해 Biorescue (Biorescue, RM Ingenierie, France)를 이용하였다. 이 장비는 center of pressure (COP)를 감지하는 발판과 데이터 컴퓨터 수집장치를 이용하여 압력 중심의 이동 거리, 이동 면적, 이동 속도를 측정할 수 있다. 이 중 이동 거리를 균형 능력 
변화 측정값으로 이용하였고 측정값이 작아지면 균형조절 능력이 향상됨을 나타낸다. 측정값은 바로 선 양발 지지 자세에서 눈 뜨고, 눈 감은 상태에서 정적 균형 능력을 3 회 측정한 값을 균형 능력 지수 로 이용하였다. 측정시간은 1 분간 중심을 잡도록 하였고 측정 간에 1 분의 휴식시간이주어졌다.

\section{4. 분석 방법}

모든 자료는 SPSS ver. 18.0 통계 프로그램을 이용하였고 대상자에 일반 적 특성의 정규분포를 알아보기 위해 단일표본 Kolmogorov-smirnov 검정을 하여 정규분포가 인정되어 두 그룹의 실험 전과 실험 4 주 후 실험 8 주 후의 측정 변인에 대한 변화를 알아보기 위해 반복측정분 산분석(repeated measure ANOVA)을 이용하였다. 개체내효과 검정에 서 시기와 군 간 상호작용이 있는 경우에는 일원배치분산분석(oneway ANOVA)을 하였고 사후검정으로 Scheffe 다중비교분석을 하였 다. 통계학적 유의성을 검정하기 위해 0.05 로 설정하였다.

\section{결 과}

\section{1. 넙다리곧은근 힘줄 두께 변화}

각 군의 넙다리곧은근 힘줄 두께 변화에 대한 반복측정분산분석 결 과 시기별, 시기와 군 간 상호작용, 집단 간 변화에서 유의한 차이가 있었다 $(\mathrm{p}<0.05)($ Table 2$)($ Figure 1$)$.

\section{2. 아킬레스힘줄 두께 변화}

각 군의 아킬레스힘줄 두께 변화에 대한 반복측정분산분석 결과 시 기별, 시기와 군 간 상호작용, 집단 간 변화에서 유의한 차이가 있었 다 $(\mathrm{p}<0.05)$ (Table 2)(Figure 1).

\section{3. 눈뜨고 양발 정적 균형 변화}

각 군의 눈 뜨고 양발 정적 균형 변화에 대한 반복측정분산분석 결과 시기별, 시기와 군 간 상호작용에서 유의한 차이가 있었고 $(\mathrm{p}<0.05)$, 집

Table 2. Comparison of tendon thickness and balance

$(\mathrm{mm})(\mathrm{cm})$

\begin{tabular}{|c|c|c|c|c|c|c|c|c|}
\hline & & \multirow{2}{*}{ Pre (a) } & \multirow{2}{*}{4 weeks (b) } & \multirow{2}{*}{8 weeks (c) } & \multicolumn{3}{|c|}{$\mathrm{F}$} & \multirow{2}{*}{ Post-hoc } \\
\hline & & & & & Time & TimeX Group & Group & \\
\hline \multirow[t]{2}{*}{ RFT } & BKE & $0.25 \pm 0.29$ & $0.27 \pm 0.33$ & $0.30 \pm 0.38$ & $64.326^{*}$ & $42.479^{\star}$ & $7.546^{*}$ & $a<c$ \\
\hline & KE & $0.24 \pm 0.27$ & $0.24 \pm 0.35$ & $0.24 \pm 0.32$ & & & & \\
\hline \multirow[t]{2}{*}{ AT } & BKE & $0.48 \pm 0.06$ & $0.52 \pm 0.07$ & $0.56 \pm 0.06$ & $76.815^{*}$ & $63.740^{*}$ & $4.594^{*}$ & $a<c$ \\
\hline & $\mathrm{KE}$ & $0.45 \pm 0.11$ & $0.44 \pm 0.10$ & $0.45 \pm 0.10$ & & & & \\
\hline \multirow[t]{2}{*}{ OEDS } & BKE & $20.90 \pm 6.96$ & $18.20 \pm 5.39$ & $15.09 \pm 4.15$ & $9.439^{*}$ & $23.701^{*}$ & 1.394 & $a<c$ \\
\hline & KE & $19.60 \pm 5.73$ & $21.10 \pm 6.85$ & $21.00 \pm 6.16$ & & & & \\
\hline \multirow[t]{2}{*}{ CEDS } & BKE & $24.75 \pm 6.72$ & $21.82 \pm 6.48$ & $18.34 \pm 6.20$ & $9.616^{*}$ & $45.030^{*}$ & 0.954 & $a<c$ \\
\hline & KE & $23.37 \pm 9.13$ & $24.66 \pm 10.79$ & $25.75 \pm 9.52$ & & & & \\
\hline
\end{tabular}

RFT: rectus femoris tendon thickness, AT: achilles tendon thickness, OEDS: open eye double support, CEDS: close eye double support, BKE: blood flow restriction knee extension exercise, KE: knee extension exercise. Post-hoc: one way ANOVA. ${ }^{*} \mathrm{p}<0.05$.

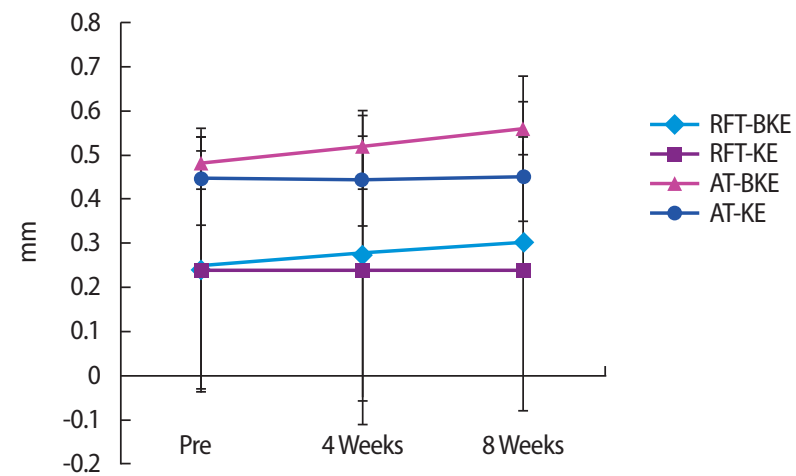

Figure 1. Comparison of quadriceps tendon and achilles tendon thickness. RFT-BKE: rectus femoris tendon-blood flow restriction knee extension exercise, RFT-KE: rectus femoris tendon-knee extension exercise, AT-BKE: achilles tendon thickness-blood flow restriction knee extension exercise, AT-KE: achilles tendon thickness-knee extension exercise.

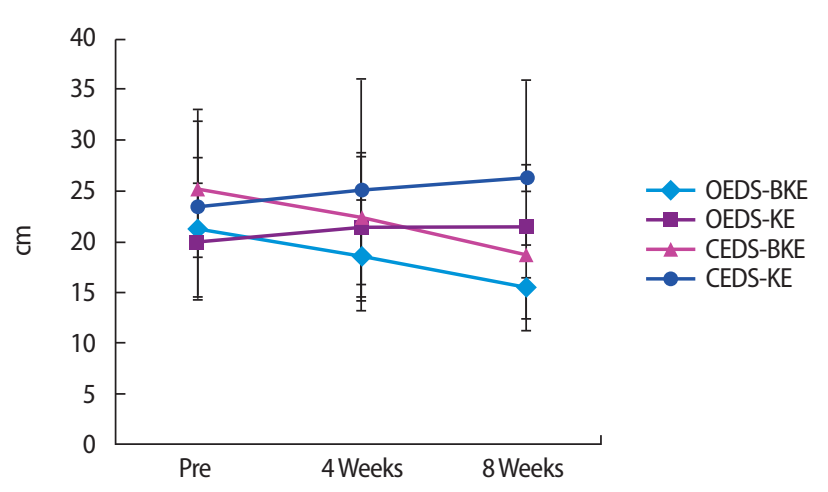

Figure 2. Comparison of eye open and eye close balance. OEDS-BKE: open eye double support-blood flow restriction knee extension exercise, OEDS-KE: open eye double support-knee extension exercise, CEDS-BKE: close eye double support-blood flow restriction knee extension exercise, CEDS-KE: close eye double support-knee extension exercise. 
단 간 변화에서는 유의한 차이가 없었다(p>0.05)(Table 2)(Figure 2).

\section{4. 눈감고 양발 정적 균형 변화}

각 군의 눈 감고 양발 정적 균형 변화에 대한 반복측정분산분석 결 과 시기별, 시기와 집단 간 변화에서 유의한 차이가 있었고 $(\mathrm{p}<0.05)$, 집단 간 변화에서는 유의한 차이가 없었다( $p>0.05$ )(Table 2)(Figure 2).

\section{고 찰}

본 연구는 건강한 성인 남녀 30 명을 대상으로 8 주간 커프를 이용하 여 혈류제한을 적용한 무릎 폄 운동군과 커프를 적용하지 않은 일반 적 무릎 폄 운동군으로 나누어 초음파를 이용하여 넙다리곧은근 힘 줄과 아킬레스힘줄의 두께 변화와 균형 능력 장비를 이용하여 양발 지지 자세에서 눈뜨고, 눈 감고 균형 능력 변화를 알아보고자 실험 전, 4 주 후, 8 주 후로 시기를 나누어 진행하였다. 본 연구에서 이용된 초음파는 고해상도 영상의 질적 향상으로 관절 주변 조직들을 효과 적으로 관찰할 수 있으며, ${ }^{20}$ 심부 구조물을 측정하기에 적합한 장비 이다. ${ }^{21}$ 또한 신뢰도 연구에서 신뢰도가 높게 나와 심부 구조 변화 측 정에 자주 이용되고 있다. ${ }^{22}$

그 결과 넙다리곧은근 힘줄과 아킬레스힘줄의 두께 변화는 시기 별, 시기와 군 간 상호작용, 군 간 변화에서 유의한 차이가 있었다 $(\mathrm{p}<0.05)$.

최근 힘줄 세포의 증식을 유도하는 여러 성장인자의 중요성에 주 목하고 있다.23 그 중 인슐린양성인자(insulin-like growth factor 1, IGF1)는 힘줄 세포의 증식을 촉진한다. ${ }^{24,25} \mathrm{IGF}-1$ 을 생성하도록 유도하는 방법은 여러 가지가 있지만, 저산소 환경을 유발하는 혈류제한 방법 이 가능성이 있다. ${ }^{26} \mathrm{Sata}^{27}$ 는 혈류제한 운동을 1RM (repetition maxi$\mathrm{mum})$ 의 $30 \%$ 강도로 3 주 동안 실시한 결과 넙다리부의 근 위축이 예 방되어 힘줄 건강에 도움이 된다고 하였고, 또 다른 연구에서는 혈류 제한 운동이 뼈 연골에 도움이 된다고 하였다. ${ }^{28}$ 혈류제한 운동은 무 산소 환경을 조성하여 성장호르몬의 양을 증가시키고 ${ }^{15}$ 성장호르몬 은 근육과 연골, 뼈의 성장에 관여하며, IGF-1의 합성을 유발한다. 29 이 러한 변화가 힘줄에 영향을 미친 것으로 생각되며, 혈류제한운동 휴 식시간 차이가 성장호르몬과 IGF-1 분비에 미치는 연구에서 90초의 휴식시간을 주어진 군에서 30 초 휴식시간을 준 군과 혈류제한을 하 지 않은 다른 군보다 성장호르몬과 IGF-1의 유의한 증가가 있었다고 보고하여,,$^{30}$ 세트당 1 분씩 휴식시간이 주어진 본 연구에서 성장호르 몬과 IGF-1의 증가가 발생하여 이러한 결과가 발생한 것으로 생각된 다. 저산소 환경에서 신생혈관(angiogenesis)과 뼈 성장(bone development)의 역할을 뒷받침하는 연구가 점점 늘어나고 있다. ${ }^{31}$ 저산소 환 경에 노출되면 혈관내피성장인자(vascular endothelial growth factor,
VEGF)의 활성화를 유발한다. ${ }^{32} \mathrm{VEGF}$ 는 일산화질소(NO) 등의 혈관 작용물질을 생산함으로써 혈관 활성의 조절에 중요한 역할을 하여 신생 혈관을 증식시키는 변화가 발생한다. ${ }^{17}$ 이와 관련 연구로는 Takano 등은 혈류제한이 VEGF의 분비를 촉진한다고 하였고, $\mathrm{Kim}^{33}$ 은 혈류제한 저강도 운동을 이용하여 지근과 관련된 $\alpha$-운동신경원 의 흥분 변화 연구에서 대조군과 차이가 없다고 보고하여, 혈류제한 운동의 지구력 개선 효과는 신생혈관 발달로 인해 변화된 것을 지지 한다. ${ }^{18,19}$ 아직 관절 주변의 생화학적 변화와 형태학적 변화에 대해 보 고가 없어 단정지을 수는 없지만 본 연구에서 무릎 폄 운동에 관여가 적었던 아킬레스 힘줄의 두께 증가를 보면 혈류제한의 효과인 신생 모세혈관의 발달로 인해 관절 주변의 조직에 충분한 성장인자와 혈 액 동태를 변화시킴으로써 힘줄에도 영향을 준 결과로 생각되며, 일 원배치분산분석 결과, 8 주만에 힘줄의 두께 변화가 발생한 이유는 Loenneke 등 ${ }^{34}$ 은 혈류제한 압력을 모든 대상에게 일률적으로 적용할 경우 중재의 효과가 감소한다고 하였는데 본 연구에서 압력은 1 주에 서 4주까지는 $150 \mathrm{mmHg}$ 를 4주에서 8 주까지는 $200 \mathrm{mmHg}$ 의 압력의 차이에 따라 힘줄 두께 변화에도 긍정적 효과가 발생한 것으로 생각 된다.

균형능력을 증가시키는 운동은 많지만, 고유수용성 감각 훈련과 더불어 근력 강화도 균형능력 향상에 도움이 된다. Willems 등 35 은 발 목 불안정성 원인으로 근력의 저하를 언급하며 근력 강화의 필요성 을 강조하였고, Blackburn 등 36 은 고유수용성 감각 훈련과 근력 훈련 간의 효과 비교 연구에서 방법 간의 유의한 차이가 없어 고유수용성 감각 훈련과 더불어 근력 훈련 또한 균형 능력에 효과적인 훈련 방법 이라고 하였다. 본 연구에서 측정된 넙다리곧은근 힘줄과 아킬레스 힘줄은 넙다리곧은근과 장딴지근, 넙치근과 연결되어 있으므로 다 리 근력 강화는 균형에도 영향을 미칠 것으로 생각하고 측정한 결과 양발 지지 자세에서 눈 뜨고 눈 감고 변화는 시기별, 시기와 군 간 상 호작용에서 유의한 차이가 있었고 $(\mathrm{p}<0.05)$, 군 간 변화에서는 유의한 차이가 없었다 $(\mathrm{p}>0.05)$.

Jun과 Park'은 다리 근육은 서 있는 동안 신체를 지탱하므로 다리 근력 강화의 필요성을 언급하면서 혈류제한을 이용한 계단 운동이 무릎관절 폄 근의 근력을 증가시켰다고 보고하였고, 또 다른 연구에 서는 혈류제한 운동이 노인들의 보행 질을 향상했다고 보고하여, ${ }^{37}$ 측정 변수는 다르지만 선행연구와 비슷한 결과가 발생하였다. 이러 한 결과는 다리 근육 강화 운동이 균형능력에 효과적이라고 한 연구 처럼 혈류제한 운동으로 인한 효과인 근육 발달로 인한 결과로 생각 된다. ${ }^{38}$ 하지만 군 간 차이가 없었던 이유는 상호작용 효과가 유의한 주효과를 가리는 가면 효과(masking effect)로 인해 이러한 결과가 발 생한 것으로 생각된다. ${ }^{39}$

본 연구는 초음파와 균형장비만 이용하여 생리학적 변화를 확인 
하지 못하였고 특정 연령대와 대상자 수가 적어 일반화하기에는 무 리가 있지만 혈류제한 운동이 힘줄에 긍정적인 영향을 미쳐 힘줄 강 화에 효과적인 운동 방법임을 확인하였다. 하지만 심혈관계질환 환 자들은 말초조직으로 혈액이 도달하기 어렵게 제한하고 심장으로 혈액이 회귀하기 어렵게 제한하는 이런 종류의 운동은 주의가 필요 하며 적절한 중재가 필요해보인다. 향후 본 연구에서 확인하지 못한 힘줄과 관련하여 생리학적 변화와 관절 역학적 운동의 변화, 대상자 의 다변화를 통해 후속 연구가 계속되었으면 한다.

혈류제한을 이용한 운동방법은 임상에서 힘줄 강화를 위한 방법 으로 유용할 것으로 보이며 힘줄 강화 훈련 중재 방법으로 근거를 제 시할수 있을 것으로 생각된다.

\section{Acknowledgements}

이 논문은 2017년도 남부대학교 학술연구비의 지원을 받아 연구되었다.

\section{참고문헌}

1. Franchi M, Quaranta M, De Pasquale V et al. Tendon crimps and peritendinous tissues responding to tensional forces. Eur J Histochem. 2007; 51(1):9-14.

2. Lynch RM. Achilles tendon rupture: Surgical versus non-surgical treatment. Accid Emerg Nurs. 2004;12(3):149-58.

3. Sakabe T, Sakai T. Musculoskeletal diseases-tendon. Br Med Bull. 2011;99(1):211-25.

4. Sharma P, Maffulli N. Biology of tendon injury: Healing, modeling and remodeling. J Musculoskelet Neuronal Interact. 2006;6(2):181-90.

5. Okamoto N, Kushida T, Oe K et al. Treating achilles tendon rupture in rats with bone-marrow-cell transplantation therapy. J Bone Joint Surg Am. 2010;92(17):2776-84.

6. Huang TF, Yew TL, Chiang ER et al. Mesenchymal stem cells from a hypoxic culture improve and engraft achilles tendon repair. Am J Sports Med. 2013;41(5):1117-25.

7. Takano H, Morita T, Iida H et al. Hemodynamic and hormonal responses to a short-term low-intensity resistance exercise with the reduction of muscle blood flow. Eur J Appl Physiol. 2005;95(1):65-73.

8. Abe T, Kearns CF, Sato Y. Muscle size and strength are increased following walk training with restricted venous blood flow from the leg muscle, Kaatsu-walk training. J Appl Physiol. 2006;100(5):1460-6.

9. Jun JY, Park MC. The effect of stair exercise with restriction blood flow on knee extensor muscle. J Korean Soc Phys Med. 2015;10(4):9-14.

10. Yasuda T, Fukumura K, Fukuda T et al. Muscle size and arterial stiffness after blood flow-restricted low-intensity resistance training in older adults. Scand J Med Sci Sports. 2014;24(5):799-806.

11. Park JC, Park MS, Kim YN. Effects of different sizes of blood flow restriction areas on changes in muscle thickness. J Kor Phys Ther. 2017; 29(2):80-4.

12. Park JC, Oh SK, Jeong JG. Effects of blood flow restriction and different support surfaces on the thickness of type-I muscle fibers in the trunk. J Kor Phys Ther. 2017;29(2):69-73.

13. Park JC, Kim YN. Impact of waist stabilization exercise with blood flow restriction on white area index of trunk muscle thickness density. J Kor Phys Ther. 2016;28(2):136-41.

14. Sumide T, Sakuraba K, Sawaki K et al. Effect of resistance exercise training combined with relatively low vascular occlusion. J Sci Med Sport. 2009;12(1):107-12.

15. Takarada Y, Nakamura Y, Aruga S et al. Rapid increase in plasma growth hormone after low-intensity resistance exercise with vascular occlusion. J Appl Physiol. 2000;88(1):61-5.

16. Takarada Y, Tsuruta T, Ishii N. Cooperative effects of exercise and occlusive stimuli on muscular function in low-intensity resistance exercise with moderate vascular occlusion. Jpn J Physiol. 2004;54(6):585-92.

17. Okamoto T, Masuhara M, Ikuta K. Effects of muscle contraction timing during resistance training on vascular function. J Hum Hypertens. 2009; 23(7):470-8.

18. Evans C, Vance S, Brown M. Short-term resistance training with blood flow restriction enhances microvascular filtration capacity of human calf muscles. J Sports Sci. 2010;28(9):999-1007.

19. Hunt JE, Galea D, Tufft G et al. Time course of regional vascular adaptations to low load resistance training with blood flow restriction. J Appl Physiol. 2013;115(3):403-11.

20. Kang TY. Musculoskeletal ultrasound in rheumatology. Korean J Med. 2010;78(6):687-96.

21. Rankin G, Stokes M, Newham D. Size and shape of the posterior neck muscles measured by ultrasound imaging: Normal values in males and females of different ages. Man Ther. 2005;10(2):108-15.

22. Lee JA, Kim SY. Reliability of ultrasonography for the longus colli in asymptomatic subjects. J Kor Phys Ther. 2011;23(4):59-66.

23. Seo WY, Ha JK, Kim JG et al. Treatment of chronic patellar tendinitis with platelet rich plasma injection. Korean J Sports Med. 2012;30(2): 110-5.

24. Kashiwagi K, Mochizuki Y, Yasunaga Y et al. Effects of transforming growth factor-beta 1 on the early stages of healing of the achilles tendon in a rat model. Scand J Plast Reconstr Surg Hand Surg. 2004;38(4):1937.

25. Molloy T, Wang Y, Murrell GA. The roles of growth factors in tendon and ligament healing. Sports Med. 2003;33(5):381-94.

26. Abe T, Yasuda T, Midorikawa T et al. Skeletal muscle size and circulating igf- 1 are increased after two weeks of twice daily "Kaatsu" resistance training. Int J KAATSU Training Res. 2005;1(1):6-12.

27. Sata S. Kaatsu training for patella tendinitis patient. Int J KAATSU Training Res. 2005;1(1):29-32.

28. Loenneke JP, Young KC, Wilson JM et al. Rehabilitation of an osteochondral fracture using blood flow restricted exercise: A case review. J Bodyw Mov Ther. 2013;17(1):42-5.

29. Yakar S, Rosen CJ, Beamer WG et al. Circulating levels of igf- 1 directly regulate bone growth and density. J Clin Inves. 2002;110(6):771-81.

30. You JM, Park HC, Yoon SJ. The effects of different resting intervals in strength training with vascular occlusion on hormonal response and muscular strength. KJPE. 2008;47(6):645-58.

31. Araldi E, Schipani E. Hypoxia, HIFs and bone development. Bone. 2010; 47(2):190-6. 
32. Loenneke JP, Young KC, Fahs CA et al. Blood flow restriction: rationale for improving bone. Med Hypotheses. 2012;78(4):523-7.

33. Kim JS. Changes of $\alpha$-motor neuron excitability after low-intensity exercise with transient restriction of blood flow. J Korean Soc Phys Med. 2015;10(1):63-9.

34. Loenneke J, Thiebaud R, Abe T et al. Blood flow restriction pressure recommendations: the hormesis hypothesis. Med hypotheses. 2014;82(5): 623-6.

35. Willems T, Witvrouw E, Verstuyft J et al. Proprioception and muscle strength in subjects with a history of ankle sprains and chronic instability. J Athl Train. 2002;37(4):487-93.
36. Blackburn T, Guskiewicz KM, Petschauer MA et al. Balance and joint stability: The relative contributions of proprioception and muscular strength. J Sport Rehabil. 2000;9(4):315-28.

37. Clarkson MJ, Conway L, Warmington SA. Blood flow restriction walking and physical function in older adults: A randomized control trial. J Sci Med Sport. 2017;20(12):1046-6.

38. Jang WS, Bae SS, Ju MY et al. Influence of lower extremity strengthening exercise on sway area of knee osteoarthritis. J Korean Soc Phys Med. 2006;1;(1):13-21.

39. Sung NK. Analysis and experiment of repetitive measurement. Paju, Free Academy, 1997:113. 